\title{
Investigation on the Relationship between Information Communication Technology and Reading Literacy for Northeast Asian Students
}

\author{
Yi-Horng Lai \\ Oriental Institute of Technology, Department of Healthcare Administration, 22061 New Taipei City, Taiwan
}

\begin{abstract}
The purpose of this study was to investigate the relationship of internet communication technologies (ICT) usage and reading literacy of Northeast Asian Students in PISA 2009. ICT was crucial for all governments in the world towards promoting equity. ICT had been considered a low cost opportunity towards equalizing educational systems. A multilevel modelling (MLM) was applied to identify at which school-level the largest variations in the three indicators exist in this study. With MLM, it could be examine simultaneously the effects of different hierarchical school-level variables; to take account of possible correlations of students' reading literacy in this study within higher levels (Urbanization, Total number of students Computers for education) which may otherwise lead to incorrect standard errors and inefficient estimates; to treat higher levels as related; and to examine inter-area variations at each level. The empirical results include the different between group components was significant. Selfconfidence in ICT high level tasks was positive with students' reading literacy, and self-confidence in ICT high level tasks was negative with students' reading literacy. The urbanization of schools' area and total number of students of schools were positive with students' reading literacy. The urbanization of schools' area was negative with the relationship of ICT for school related tasks and students' reading literacy. Total number of students was negative with the relationship of ICT for school related tasks and students' reading literacy, and ICT availability in school and students' reading literacy.
\end{abstract}

\section{General instruction}

The purpose of this study was to investigate the relationship of Internet Communication Technologies (ICT) usage and reading literacy of Northeast Asian Students in PISA 2009. Studies on educational efficiency have been on the rise in the past decade. Since, investments in education pays back in the long run, this leads countries to evaluate educational systems with their functions based on student achievement. ICT was crucial for all governments in the world towards promoting equity. ICT had been considered a low cost opportunity towards equalizing educational systems.

These years, scholars were often confronted with the collection of correlated data. This generic term hold a multitude of data structures, such as multivariate observations, repeated measurements, clustered data, longitudinal data, and spatially correlated data. Instances of this type of research can be encountered in virtually every empirical branch of science. Different areas of research will refer to the same or similar concepts with different terminology. Such as multilevel modelling [1] was a frequently encountered term in sociological applications, whereas in classical experimental design research one often re-fers to variance component models [2]. A multilevel modelling can consist of more than two levels and examples also abound in practice. Schooling systems, for instance, present an obvious multilevel structure, with pupils grouped into classrooms, which are nested within schools which themselves may be clustered within education authorities [3, 4].

A multilevel modelling (MLM) was applied to identify at which school-level the largest variations in the three indicators exist in this study. With MLM, it could be examine simultaneously the effects of different hierarchical school-level variables; to take account of possible correlations of outcomes (students' reading literacy in this study) within middle or higher levels which may otherwise lead to in-correct standard errors and inefficient estimates; to treat middle and higher levels as related; and to ex-amine inter-area variations at each level.

The ICT resources for students include home ICT resource and school ICT resource [5, 6, \& 7]. ICT connects information, products, ideas, people, individuals as well as communities globally at a low cost. Peoples worry the importance of preparation of young generations with ICT skills in their education policy documents. ICT brings new structures in learning. In PISA survey, students are asked about their familiarity with ICT, mainly with computers.

Previous studies that survey the relationship be-tween ICT usage and problem-solving found that when students have access to computers at home, they had better

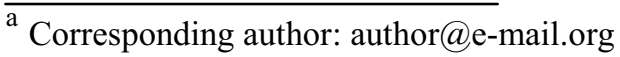


achievement scores [8]. With 297295 fifteen-year-old students in PISA 2009 data, Lee and Wu indicate that ICT availability at home and self-confidence in ICT high level tasks was positive with students' reading literacy [9]. Besides, with enough ICT resource at home, students need more help in self-confidence in ICT high level tasks and ICT for school related tasks for improve reading literacy, now [10]. Although lots of studies point out that computers are helpful in students' reading literacy, Tse, Yuen, Loh, Lam, \& $\mathrm{Ng}$ recommend that computers can have a beneficial impact on students' reading but only if computer usage is well targeted and does not consist of students playing repetitive games [11].

\section{Materials and methodology}

The research frame was as Figure 1. School-level variables include urbanization, total number of students, and computers for education. Student-level variables include self-confidence in ICT, high level tasks, ICT for school related tasks, ICT availability at home, and ICT availability in school. The Hypothesis 1 is the studentlevel variables were positive with reading literacy. The Hypothesis 2 is the school-level variables were positive with reading literacy. The Hypothesis 3 is the studentlevel variables were positive with reading literacy dependent on school-level variables.

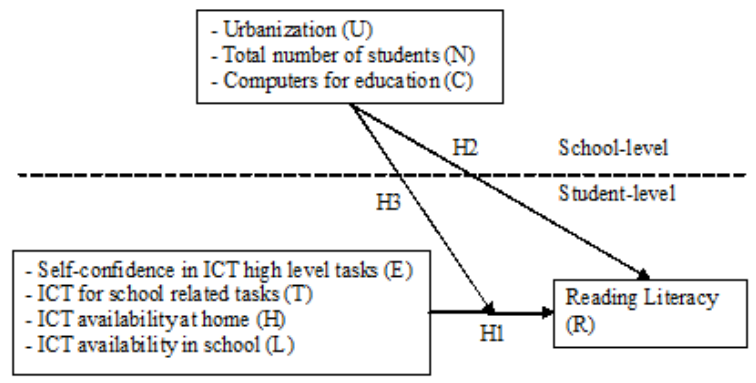

Figure 1. Research framework of this study.

\subsection{Research Data}

The primary source of data for our analysis is the fourth wave of the Programme for International Stu-dent Assessment (PISA) administered in 2009. PISA is a cross national survey that, every three years since 2000 , has assessed 15 year-old students' performance in mathematics, reading and science, as well as crosscurricular problem-solving skills. PISA considers students' knowledge in these areas not in isolation, but in relation to their ability to reflect on their knowledge and experience and apply them to real-world issues. The emphasis is on mastering pro-cesses, understanding concepts and functioning in various contexts within each assessment area [12].

\subsection{Data Analysis}

In this study, a two multi-level be estimated with random intercepts models. The multilevel modelling (MLM) was applied to identify at which school-level the largest variations in the three indicators exist in this study. The two-level model of reading literacy was as Figure 2. Multilevel models were derived using the computer package Mplus 7.0 and R 3.2.0.

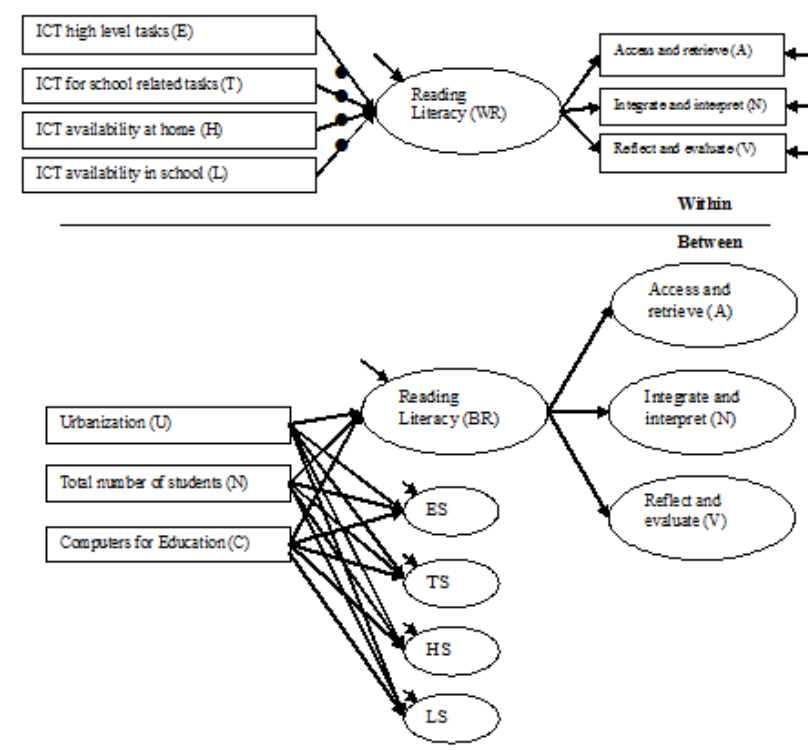

Figure 2. Two-level CFA model of reading literacy.

\section{Results}

The sample includes 10199 students from 343 schools in PISA 2009 data in Japan and Korea. The sample consisted of $41.92 \%$ female and $58.08 \%$ male students. 186 Japanese schools and 157 Korean schools, and the data summarize of student-level and school-level was as Table 1. Besides, only Japan and Korea do ICT survey in PISA 2009 data. The Cronbach's $\alpha$ of reading literacy was 96 .

Table 1. Data summarize of student-level and school-level.

\begin{tabular}{|l|l|r|r|r|r|}
\hline & & \multicolumn{2}{|c|}{ Student-level } & \multicolumn{2}{c|}{ School-level } \\
\hline Geographic & & \multicolumn{1}{|c|}{ Freq. } & \multicolumn{1}{c|}{$(\mathbf{\%})$} & \multicolumn{1}{c|}{ Freq. } & \multicolumn{1}{c|}{$\mathbf{( \% )}$} \\
\hline \multirow{3}{*}{ Gender } & Male & 4923 & 41.92 & - & - \\
\cline { 2 - 6 } & Female & 5276 & 58.08 & - & - \\
\hline \multirow{5}{*}{ Urbanizization } & Japan & 5455 & 53.49 & 186 & 54.23 \\
\cline { 2 - 6 } & Korea & 4744 & 46.51 & 157 & 45.77 \\
\cline { 2 - 6 } & Village & 69 & .68 & 2 & .58 \\
\cline { 2 - 6 } & $\begin{array}{l}\text { Small } \\
\text { Town }\end{array}$ & 330 & 3.24 & 14 & 4.08 \\
\cline { 2 - 6 } & Town & 1948 & 19.10 & 64 & 18.66 \\
\cline { 2 - 6 } & City & 4552 & 44.62 & 151 & 44.03 \\
\cline { 2 - 6 } & Large & 3300 & 32.36 & 112 & 32.65 \\
\hline Total & City & 10199 & 100.00 & 343 & 100.00 \\
\hline
\end{tabular}

For testing the hypotheses in this study (Figure 1), multilevel linear modelling been used for data analysis in this study. This study explored the relationship in the cross-level variables with multilevel linear modelling.

\subsection{Null model}

This study explored the relationship of students' personal opinion factors and class factors, and detecting the effect of cross-level with multilevel linear modelling. The result 
of data analysis was as Table 4. The different between each class with null model were significant. With the result of the null model in this study, it could be found that the different between group components (u0) was significant $(\mathrm{u} 0=3935.25$, S.E. $<.01)$.

\subsection{Random Coefficient Model}

Random coefficient model was the model with all individual level variables. It means a regression model with all individual level variables in individual level and null model in group level. The relationship of dependent variables and independent variables in individual level could be detected with random coefficient model. The result of random coefficient model was as Table 2 . It could be found that self-confidence in ICT high level tasks $(\mathrm{E})\left(\gamma_{10}=5.78\right.$, S.E. $\left.=.75\right)$ and ICT availability at home $(\mathrm{H})\left(\gamma_{30}=.-2.97, \mathrm{~S} . \mathrm{E} .=.80\right)$ were significant, but CT for school related tasks $(\mathrm{T})\left(\gamma_{20}=-.48\right.$, S.E. $\left.=.88\right)$ and ICT availability in school (L) $\left(\gamma_{40}=.24\right.$, S.E. $\left.=.68\right)$ were not significant. With the result, self-confidence in ICT high level tasks was positive with students' reading literacy, and self-confidence in ICT high level tasks was negative with students' reading literacy.

\subsection{Contextual Model}

The percent of the direct effects that can be explained by intercept variance could be detected with contextual model. The result of contextual model was as Table 4. It could be find that urbanization $(\mathrm{U})\left(\gamma_{01}=10.63\right.$, S.E. $=$ 4.29), total number of students $(\mathrm{N})\left(\gamma_{02}=.01\right.$, S.E. $\left.=.01\right)$, and computers for education $(\mathrm{C})\left(\gamma_{03}=.03\right.$, S.E. $\left.=.03\right)$ were significant. With the result, the urbanization of schools' area and total number of students of schools were positive with students' reading literacy. Computers for education in schools were negative with students' reading literacy.

\subsection{Full Model}

The result of full model was as Table 4. It could be find that urbanization $(\mathrm{U})$ was a moderator for ICT for school related tasks $(T)$ with reading literacy $(R)\left(\gamma_{21}=-2.42\right.$, S.E. $=.99)$. Total number of students (N) were moderators for ICT for school related tasks (T) with reading literacy $(\mathrm{R})\left(\gamma_{22}<-.1\right.$, S.E. $\left.<.01\right)$ and ICT availability in school (L) with reading literacy $(\mathrm{R})\left(\gamma_{42}<\right.$ .1, S.E.<.01). With the result, the urbanization of schools' area was negative with the relationship of ICT for school related tasks and students' reading literacy. Total number of students was negative with the relationship of ICT for school related tasks and students' reading literacy, and ICT availability in school and students' reading literacy.
Table 2. The result of multilevel linear modelling.

\begin{tabular}{|c|c|c|c|c|c|}
\hline & & $\begin{array}{c}\text { Null } \\
\text { Model }\end{array}$ & $\begin{array}{c}\text { Random } \\
\text { Coefficient } \\
\text { Model }\end{array}$ & $\begin{array}{c}\text { Contextual } \\
\text { Model }\end{array}$ & $\begin{array}{c}\text { Full } \\
\text { Model }\end{array}$ \\
\hline I & $\begin{array}{l}\gamma_{00 \_} 1 \\
\gamma_{00 \_} 2 \\
\gamma_{00 \_3}\end{array}$ & $\begin{array}{r}536.54^{*} \\
(3.45) \\
529.63^{*} \\
(3.39) \\
531.01^{*} \\
(3.63) \\
\end{array}$ & $\begin{array}{r}538.13^{*} \\
(3.55) \\
531.23^{*} \\
(3.49) \\
532.54^{*} \\
(3.71) \\
\end{array}$ & $\begin{array}{r}504.19^{*} \\
(16.90) \\
496.95^{*} \\
(17.18) \\
494.51^{*} \\
(18.83) \\
\end{array}$ & $\begin{array}{r}507.48^{*} \\
(16.76) \\
500.29^{*} \\
(17.04) \\
498.05^{*} \\
(18.73) \\
\end{array}$ \\
\hline $\mathbf{U}$ & $\gamma_{01}$ & - & - & $\begin{array}{r}10.63^{*} \\
(4.29)\end{array}$ & $\begin{array}{r}9.68 \\
(4.28)\end{array}$ \\
\hline $\mathbf{N}$ & $\gamma_{02}$ & - & - & $\begin{array}{l}.01^{*} \\
(.01)\end{array}$ & $\begin{array}{l}.01^{*} \\
(.01) \\
\end{array}$ \\
\hline C & $\gamma_{03}$ & - & - & $\begin{array}{l}-.11 * \\
(.03)\end{array}$ & $\begin{array}{l}-.10^{*} \\
(.03)\end{array}$ \\
\hline $\mathbf{E}$ & $\gamma_{10}$ & - & $\begin{array}{r}.78^{*} \\
(.75) \\
\end{array}$ & $\begin{array}{l}5.76^{*} \\
(.75) \\
\end{array}$ & $\begin{array}{r}2.60 \\
(.48) \\
\end{array}$ \\
\hline $\mathbf{E}$ & $\gamma_{11}$ & - & - & - & $\begin{array}{r}.60 \\
(.90) \\
\end{array}$ \\
\hline $\mathbf{E}$ & $\gamma_{12}$ & - & - & - & $\begin{array}{r}<.01 \\
(<.01)\end{array}$ \\
\hline $\mathbf{E}$ & $\gamma_{13}$ & - & - & - & $\begin{array}{r}.01 \\
(.01) \\
\end{array}$ \\
\hline $\mathbf{T}$ & $\gamma_{20}$ & - & $\begin{array}{r}-.49 \\
(.88) \\
\end{array}$ & $\begin{array}{l}.56 \\
(.88) \\
\end{array}$ & $\begin{array}{l}8.42^{*} \\
(.01) \\
\end{array}$ \\
\hline $\mathbf{T}$ & $\gamma_{21}$ & - & - & - & $\begin{array}{r}-2.42 * \\
(.99) \\
\end{array}$ \\
\hline $\mathbf{T}$ & $\gamma_{22}$ & - & - & - & $\begin{array}{l}<-.01 * \\
(<.01)\end{array}$ \\
\hline $\mathbf{T}$ & $\gamma_{23}$ & - & - & - & $\begin{array}{r}.01 \\
(.01) \\
\end{array}$ \\
\hline $\mathbf{H}$ & $\gamma_{30}$ & - & $\begin{array}{r}-2.98^{*} \\
(.80)\end{array}$ & $\begin{array}{r}-2.97^{*} \\
(.80) \\
\end{array}$ & $\begin{array}{l}-1.84 \\
(.43) \\
\end{array}$ \\
\hline $\mathbf{H}$ & $\gamma_{31}$ & - & - & - & $\begin{array}{r}-.18 \\
(.91) \\
\end{array}$ \\
\hline $\mathbf{H}$ & $\gamma_{32}$ & - & - & - & $\begin{array}{r}<.01 \\
(<.01) \\
\end{array}$ \\
\hline $\mathbf{H}$ & $\gamma_{33}$ & - & - & - & $\begin{array}{r}<.01 \\
(.01) \\
\end{array}$ \\
\hline $\mathbf{L}$ & $\gamma_{40}$ & - & $\begin{array}{r}.25 \\
(.68) \\
\end{array}$ & $\begin{array}{r}.26 \\
(.68) \\
\end{array}$ & $\begin{array}{r}3.32 \\
(.32) \\
\end{array}$ \\
\hline $\mathbf{L}$ & $\gamma_{41}$ & - & - & - & $\begin{array}{r}-.47 \\
(.83)\end{array}$ \\
\hline $\mathbf{L}$ & $\gamma_{42}$ & - & - & - & $\begin{array}{l}<-.01^{*} \\
(<.01)\end{array}$ \\
\hline $\mathbf{L}$ & $\gamma_{43}$ & - & - & - & $\begin{array}{r}-.01 \\
(.01) \\
\end{array}$ \\
\hline & $\mathrm{r}$ & $\begin{array}{r}3518.83^{*} \\
(126.38) \\
\end{array}$ & $\begin{array}{r}534.07 * \\
(390.72) \\
\end{array}$ & $\begin{array}{r}1115.67 * \\
(400.37) \\
\end{array}$ & $\begin{array}{r}3084.30^{*} \\
(402.55) \\
\end{array}$ \\
\hline & $\mathrm{u}_{0}$ & $\begin{array}{r}3935.25^{*} \\
(384.13) \\
\end{array}$ & $\begin{array}{r}3903.16^{*} \\
(125.95) \\
\end{array}$ & $\begin{array}{r}3904.37^{*} \\
(126.04) \\
\end{array}$ & $\begin{array}{r}846.94^{*} \\
(127.91) \\
\end{array}$ \\
\hline & $\mathrm{u}_{1}$ & - & - & - & $\begin{array}{r}1089.14 \\
(12.60) \\
\end{array}$ \\
\hline & $\mathrm{u}_{2}$ & - & - & - & $\begin{array}{r}54.91 \\
(15.85) \\
\end{array}$ \\
\hline & $\mathrm{u}_{3}$ & - & - & - & $\begin{array}{r}978.87 \\
(14.57) \\
\end{array}$ \\
\hline & $\mathrm{u}_{4}$ & - & - & - & $\begin{array}{r}3846.94 \\
(11.59) \\
\end{array}$ \\
\hline & AIC & 316790.22 & 316720.26 & 316791.06 & 316799.69 \\
\hline & BIC & 316898.67 & 316857.63 & 316942.89 & 317067.20 \\
\hline
\end{tabular}

\section{Discussion and conclusion}

The data on the Northeast Asian student sample regarding their use of computers on a number of variables and their reading literacy was investigated. The results indicated that there is significant relationship between their use of ICT and reading literacy. The descriptive statistics revealed that a quite high percentage of students had access to computers. The results indicated that there was a high difference in terms of percentages between different schools.

Self-confidence in ICT high level tasks was helpful in students' reading literacy, and this result was the same as Lee and Wu's study $[9,10]$. If students want finish high 
level tasks themselves, they should read and learn more with Internet or other information communication technology. Students would improve reading literacy by ICT with the object of self-confidence high level tasks. But ICT availability (or resource) at home was harmful in students' reading literacy, and this result was the same as Tse, Yuen, Loh, Lam, and Ng's study [11]. For most of students or youth, information communication technology was a tool for online games. Most students that without teachers' advice only want play internet game. With these two student-level result, it could find that teachers play an important role in improving students' reading literacy. Teachers can improve students' reading literacy by self-confidence in ICT high level tasks in a full ICT resource at home. Be-sides, it could fund that ICT for school related tasks and ICT availability in school were not helpful in students' reading literacy. Students like learning with their wish, they don't like learning with teachers' wish.

Most study only focus on student-level variables, such as Lee and Wu's study [9, 10] and Tse, Yuen, Loh, Lam, and Ng's study [11]. The study focus on both studentlevel variables and school-level variables. The urbanization of school area and the total number of students of school were positive with students' reading literacy. Most schools in large city were also many students, so these two results were similar. The gap of students' reading literacy was large, and government should pay attention to these schools in village or small town for their weak reading literacy. Computers for education in schools were negative with students' reading literacy. Stu-dents think computers in school were for learning, and learning was active as teachers wish and unfunny. So improve students' reading literacy was not just mean lots computers in school. Teachers should let students know the meaning of reading literacy and make learning with computers more fun.

\section{References}

1. Goldstein, H., Multilevel Statistical Models. In: Kendall's Libary of Statistics 3. Arnold, London, (1995)

2. Searle, S.R., Casella, G., McCulloch, C.E., Variance Components, Wiley, New York (1992)

3. Castelli, A., Jacobs, R., Goddard, M., \& Smith, P.C., Health, policy and geography: Insights from a multilevel modelling approach, Social Science \& Medicine 92, 61-73 (2013)

4. Abrahantes, J.C., Molenberghs, G., Burzykowski, T., Shkedy, Z., Abad, A.A., \& Renard, D., Choice of units of analysis and modelling strategies in multilevel hierarchical models, Computational Statistics \& Data Analysis 47, 536-563 (2004)

5. OECD., PISA 2009 key findings, PISA. Re-trieved June 1 , 2013 from http://www.oecd.org/pisa/pisa2009keyfindings.htm, (2013)

6. Sweet, R. and Meates, A., ICT and Low Achievers: What Does PISA Tell Us? In A. Karpati (Ed.), Promoting Equity through ICT in Education: Project,
Problems, Prospects. Budapest, Hungary: OECD and Hungarian Ministry of Education (2004)

7. OECD, PISA 2009 at a glance, Paris: OECD, 2011.

8. Așkar, P. and Olkun, S., The use of ICT in schools based on PISA 2003 Data, Eurasian Journal of Educational Research 19, 15-34 (2005)

9. Lee, Y.H. \& Wu, J.Y., The effect of individual differences in the inner and outer states of ICT on engagement in online reading activities and PISA 2009 reading literacy: Exploring the relationship between the old and new reading literacy, Learning and Individual Differences 22(3), 336-342 (2012).

10. Lee, Y.H. \& Wu, J.Y., The indirect effects of online social entertainment and information seeking activities on reading literacy. Computers \& Education 67, 168-177 (2013)

11. Tse, S.K., Yuen, A.H.K., Loh, E.K.Y., Lam, J.W.I., \& Ng, R.H.W., The impact of blogging on Hong Kong primary school students' bilingual reading literacy, Australasian Journal of Educational Technology 26(2), 164-179 (2010)

12. OECD, Learning to Change: ICT in Schools, Paris:OECD (2001) 